\title{
Macrophage Cytokines Render WEHI-3B Tumor Cells Susceptible to Cytostasis by Prostaglandins
}

\author{
S. Ben-Efraim*, C. Tak ${ }^{\dagger}$ and I. L. Bonta ${ }^{\dagger}$ \\ *Department of Human Microbiology, Sackler School of Medicine, Tel-Aviv University, Tel-Aviv \\ 69978, Israel, Institute of Pharmacology, Faculty of Medicine, Erasmus University Rotterdam, P.O. \\ Box 1738,3000 RD Rotterdam, The Netherlands (Reprint requests to $I L B$ )
}

\begin{abstract}
$A B S T R A C T$. The growth of the murine myelomonocytic leukemia tumor, WEHI-3B, has been shown to be inhibited by a two-step treatment: first, incubation for one hour with either interleukin-1 (human recombinant IL-1 $\alpha$ or tumor necrosis factor (human recombinant TNF- $\alpha$ ); second, subsequent exposure to prostaglandins. Preincubation with IL-1 rendered the tumor cells more susceptible to subsequent treatment with either

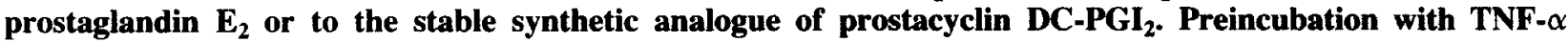
rendered the tumor cells more susceptible to further treatment with PGE $_{2}$ but not with DC-PGI . Preconditioning of the tumour cells with either IL-1 $\alpha$ or TNF $\alpha$ did not affect cytostasis by subsequent culture of tumor cells in presence of either one of the cytokines. It is concluded that the interactions between macrophage cytokines and prostaglandins in enhancement of antitumor activity might imply first binding or induction of certain moditications in the tumor cells by the cytokines which render the cells more susceptible to exposure to prostaglandins.
\end{abstract}

\section{INTRODUCTION}

Interleukin-1 (IL-1; for review see (1)) and Tumor Necrosis Factor (TNF- $\alpha$; for review see (2)), are cytokine products of macrophages expressing a wide array of biological activities, including antitumor activity $(3,4,5,6,7,8,9,10,11,12,13)$.

Occurrence of interactions between macrophage cytokines and products of arachidonic acid (AA), is well documented. Thus, inhibitors of the cyclooxygenase pathway of AA as indomethacin, augment LPS-induced IL-1 response (14). Addition of exogenous prostaglandins suppress production of IL-1 by macrophages (14). IL-1 induction of IL-2 requires participation of metabolic intermediates governed by 5-lipoxygenase activity (15). Release of TNF $\alpha$ from macrophages was found to be regulated by $\mathrm{PGE}_{2}$ (16). The interaction between AA products (eicosanoids; prostaglandins and leukotrienes), was also expressed in respect to antitumor activity. Thus, indomethacin inhibited partially the effect of IL-1 on monocyte-mediated antitumor cytotoxicity, whereas pretreatment of monocytes with prostaglandin resulted in increase of monocyte cytotoxicity (7). We reported (3), that exogenous $\mathrm{PGE}_{2}$ enhances and leukotricnc $\mathrm{C}_{4}$ inhibits

Date received 22 November 1989

Date accepted 4 January 1990
IL-1 activity against WEHI-3B tumor cells. Interaction between the two cytokines, IL-1 and TNF $\alpha$ was also reported (6) as expressed by an additive effect in destruction of tumor cells.

The synergistic effect of IL-1 and $\mathrm{PGE}_{2}$ in inhibition of WEHI-3B cell growth was demonstrated by us when IL-1 and PGE $_{2}$ were added simultaneously to tumor-cell cultures at the beginning of the incubation time (3). The aim of the present work was to determine if the synergistic antitumor cytostatic effect of a cytokine-prostaglandin combination is also exhibited when tumor cells are first treated with the macrophage cytokine and subsequently exposed to exogenous prostaglandin.

\section{MATERIALS AND METHODS}

\section{Materials}

Recombinant human interleukin-1 (HrIL-1), was a gift from Dr. S. Gillis, IMMUNEX (Seattle, Washington, USA). Recombinant Human Tumor Necrosis Factor (HrTNF- $\alpha$ ) was a gift from Dr. W. Fiers, University of Ghent, Belgium. Prostaglandin $\mathrm{E}_{2}\left(\mathrm{PGE}_{2}\right)$ and the stable synthetic analogue of prostacyclin (DC-PGI $; 5 \mathrm{E}-13,14$-didehydro-carboprostacyclin), were purchased from Sigma Chemicals Co. (St. Louis, MO, USA). HrIL-1 $\alpha$ and $\mathrm{HrTNF} \alpha$ concentrations are given in arbitrary units; $100 \mathrm{U} \quad \mathrm{IL}-1 \alpha / \mathrm{ml}=1 \mathrm{ng} / \mathrm{ml} ; 1 \mathrm{U} \quad \mathrm{TNF}$ - 
$\alpha / \mathrm{ml}=0.1 \mathrm{ng} / \mathrm{ml}$ ). Complete medium included RPMI-1640 medium (GIBCO, Grand Island, NY, USA), fetal calf serum (Sambio b.v., Uden, Holland), penicillin-streptomycin mixture and, glutamine and bicarbonate from Flow Lab. (Irvine, UK). ${ }^{3} \mathrm{H}$-thymidine $\left({ }^{3} \mathrm{HdT}\right)$ was ordered from Amersham International (Amersham, UK). All tissue-culture reagents and plastics were bought presterilized.

\section{Effect of cytokines and prostaglandins on WEHI-3B growth}

WEHI-3B tumor cells were cultured $\left(37^{\circ} \mathrm{C}, 7.5 \%\right.$ $\mathrm{CO}_{2}$ ) in $25-\mathrm{cm}^{3}$ as previously described (17). Briefly, WEHI-3B $\left(10^{3}\right.$ cells $/ 100 \mu$ l complete medium $)$, were incubated in 96-well multiwell dishes for $24 \mathrm{~h}$. ${ }^{3} \mathrm{HdT}(0.5 \mu \mathrm{Ci} / 50 \mu \mathrm{l} /$ well $)$, was than added and the multiwell dishes were incubated for further $18 \mathrm{~h}$ period. The cells were harvested and the incorporated radioactivity counted in a scintillation counter. The cytostatic effect of cytokines and prostaglandins on WEHI-3B growth (inhibition of ${ }^{3} \mathrm{HdT}$ incorporation) was determined under two experimental conditions; first, pretreatment with cytokine for one hour at $37^{\circ} \mathrm{C}$, washing and subsequent addition of prostaglandin or cytokine at the beginning of $42 \mathrm{~h}$ incubation time; second, simultaneous addition at the beginning of incubation time of cytokine and prostaglandin either alone or in various combinations. Each prostaglandin and cytokine was added in a volume of $25 \mu \mathrm{l} /$ well.

Controls of WEHI-3B cells alone were supplemented with an appropriate volume of medium only. Each kind of treatment and controls were done in 5 parallel samples and each experiment was repeated at least 3 times with similar results. Stock solutions of $\mathrm{PGE}_{2}$ and $\mathrm{DC}-\mathrm{PGI}_{2}$ in ethanol, were diluted to final concentrations in complete medium. The final concentration of ethanol in each well was proven to have no effect on WEHI-3B growth.

\section{RESULTS}

\section{Effect of simultaneous addition of cytokines and} prostaglandins on WEHI-3B growth

We confirmed previous results (3) showing synergistic effect of IL-1 and $\mathrm{PGE}_{2}$ in inhibition of WEHI-3B cell growth (results not shown here). A similar synergistic effect was now found between IL1 and $\mathrm{PGI}_{2}$ (Fig. 1).

TNF $\alpha$ alone was cytostatic at a high dose of $1000 \mathrm{U} / \mathrm{ml}$ and this effect was additively reinforced by simultaneous addition of $\mathrm{IL}_{1 \alpha}(100 \mathrm{U} / \mathrm{ml})$ (Fig. 2). A synergistic cytostatic effect was shown to occur between TNF $\alpha(1000 \mathrm{U} / \mathrm{ml})$ and $100 \mathrm{ng} / \mathrm{ml}$ $\mathrm{PGE}_{2}$ (Fig. 3). On the other hand, no such syner-



Fig. 1 Cytostatic effect on WEHI-3B cells of simultaneous addition of $\mathrm{IL}_{1 \alpha}$ and $\mathrm{PGI}_{2}$ at the beginning of incubation time.

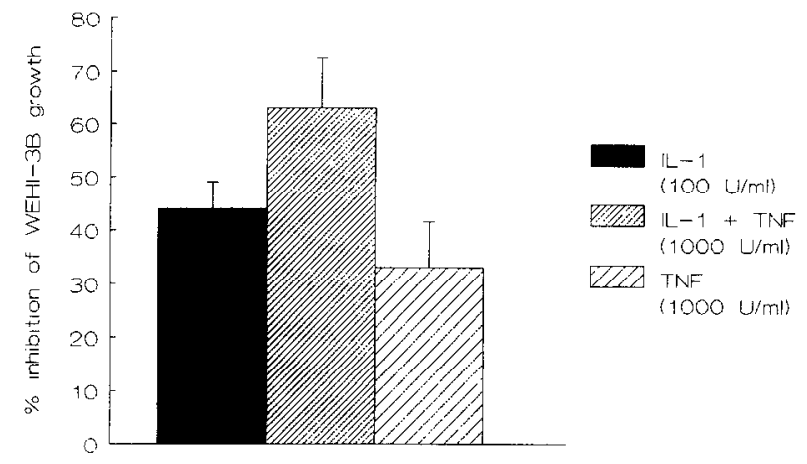

Fig. 2 Cytostatic effect on WEHI-3B of simultaneous addition of $\mathrm{II}_{1 \mathrm{lu}}$ and TNFo at the heginning of incubation time.

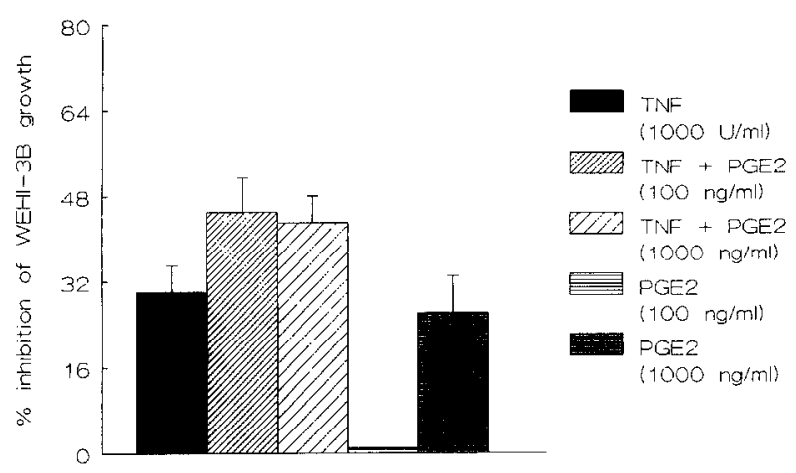

Fig. 3 Cytostatic effect on WEHI-3B cells of simultaneous addition of TNF $\alpha$ and $\mathrm{PGI}_{2}$ at the beginning of incubation time.

gistic effect was observed in a combination of TNF $\alpha$ $(1000 \mathrm{U} / \mathrm{ml})$ and $\mathrm{PGI}_{2}(1.25$ or $12.5 \mathrm{ng} / \mathrm{ml}$; Fig. 4). Quantities of $\mathrm{PGI}_{2}$ higher than $12.5 \mathrm{ng} / \mathrm{ml}$ were markedly cytostatic; $75 \%$ and $91 \%$ inhibition of ${ }^{3} \mathrm{IIdT}$ incorporation for $\mathrm{PGI}_{2} 125$ and $1250 \mathrm{ng} / \mathrm{ml}$, respectively).

\section{Effect of pretreatment with IL-1 $\alpha$ or TNF $\alpha$ on subsequent exposure to prostaglandins}

Pretreatment with $\mathrm{IL}_{1 \alpha}(100 \mathrm{U} / \mathrm{ml})$ increased cytostasis by subsequent exposure of WEHI-3B cells to 



(1.25 $\mathrm{ng} / \mathrm{ml})$

ZXT TNF + PG12 (12.5 ng/ml)

PGI2

$\{1.25 \mathrm{ng} / \mathrm{ml}\}$

PG'2

$(12.5 \mathrm{ng} / \mathrm{ml})$

Fig. 4 Cytostatic effect on WEHI-3B cells simultaneous addition of $\mathrm{TNF} \alpha$ and $\mathrm{PGI}_{2}$ at the beginning of incubation time; same suspension of WEHI-3B cells was used as in exp. brought in Fig. 3; cytostatic ${ }^{f f e c t}$ of TNF $\alpha$ alone is given for comparison.

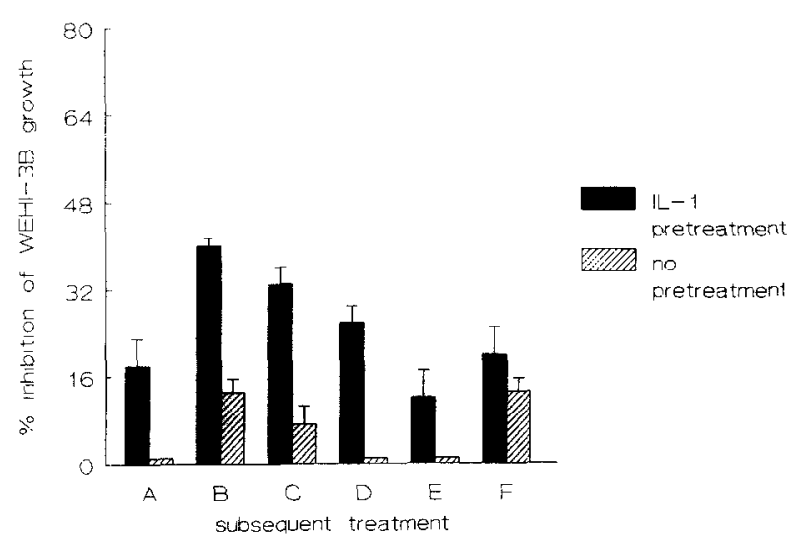

Fig. 5 Cytostatic effect on WEHI-3B cells of prior treatment with IL-1 $(100 \mathrm{U} / \mathrm{ml}$ in $\mathrm{A}, \mathrm{B}, \mathrm{C}, \mathrm{D} ; 10 \mathrm{U} / \mathrm{ml}$ in $\mathrm{E}, \mathrm{F})$ on subsequent treatment with $\mathrm{PGE}_{2}$ ( $\mathrm{A}$ and $\mathrm{E}=$ no subsequent treatment; $\mathrm{B}$ and $\mathrm{F}=\mathrm{PGE}_{2}, 1000 \mathrm{ng} / \mathrm{ml} ; \mathrm{C}=\mathrm{PGE}_{2}$, $100 \mathrm{ng} / \mathrm{ml} ; \mathrm{D}=\mathrm{PGE}_{2}, 10 \mathrm{ng} / \mathrm{ml}$ ).

$\mathrm{PGE}_{2}(10-1000 \mathrm{ng} / \mathrm{ml})$. The effect was also evident by pretreatment with $10 \mathrm{U} / \mathrm{ml} \mathrm{IL}_{1 \alpha}$ (Fig. 5). Pretreatment with $\mathrm{IL}_{1 \alpha}(100 \mathrm{U} / \mathrm{ml})$ increased also cytostasis by subsequent exposure of WEHI-3B cells to $\mathrm{PGI}_{2}, 12.5 \mathrm{ng} / \mathrm{ml}$ (Fig. 6).

Prior treatment with TNF $\alpha \quad(1000 \mathrm{U} / \mathrm{ml})$, rendered the WEHI-3B cells susceptible to subsequent treatment with $\mathrm{PGE}_{2}$ but not to subsequent treatment with $\mathrm{PGI}_{2}$ (Fig. 7).

\section{Effect of pretreatment with IL-1 or TNF on subsequent exposure to the same or to the unrelated cytokine}

Pretreatment with IL-1 $\alpha(100 \mathrm{U} / \mathrm{ml})$, had no effect on subsequent exposure to either IL $\alpha$ itself or to TNF $\alpha$ (Fig. 8). Pretreatment with TNF $\alpha$ did also not affect cytostasis toward WEHI-3B cells by subsequent exposure to either TNF $\alpha$ or to IL-1 $\alpha$ (Fig. 8). Prior treatment with either one of the cytokines without subsequent exposure did not affect ap-

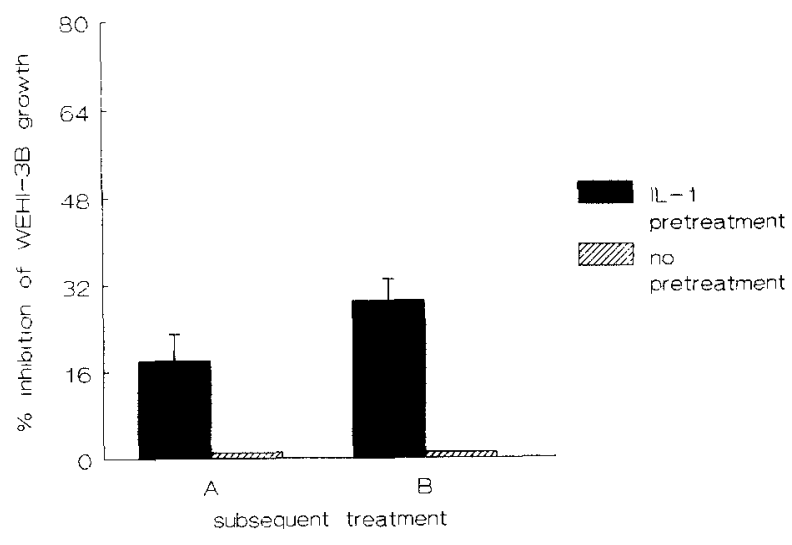

Fig. 6 Cytostatic effect on WEHI-3B cells of prior treatment with $\mathrm{IL}_{1 \alpha}(100 \mathrm{U} / \mathrm{ml})$ on subsequent treatment with $\mathrm{PGI}_{2}$ (A $=$ no subsequent treatment; $\mathrm{B}=\mathrm{PGI}_{2}, 12.5 \mathrm{ng} / \mathrm{ml}$ ).

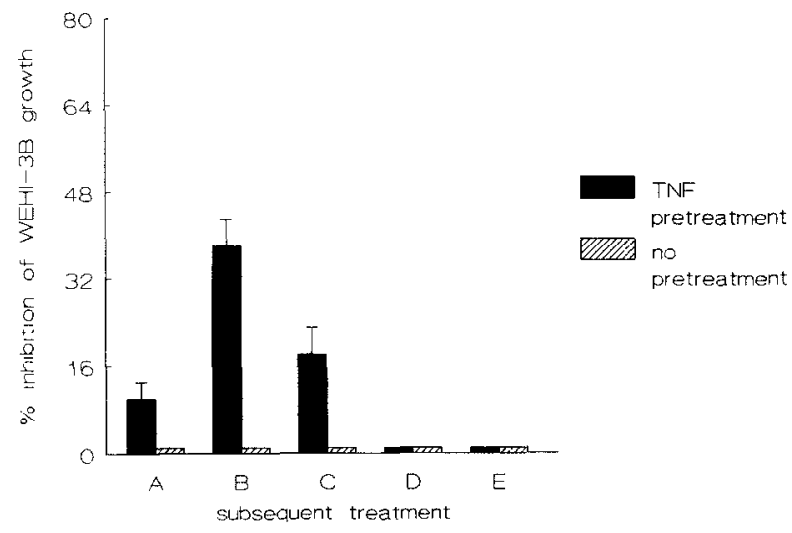

Fig. 7 Cytostatic effect on WEHI-3B cells of prior treatment with TNF $\alpha(1000 \mathrm{U} / \mathrm{ml})$ on subsequent treatment with PG's $\left(A=\right.$ no subsequent treatment; $B=P G E_{2}, 1000 \mathrm{ng} / \mathrm{ml}$; $\mathrm{C}=\mathrm{PGE}_{2}, 100 \mathrm{ng} / \mathrm{ml} ; \mathrm{D}=\mathrm{PGI}_{2}, 12.5 \mathrm{ng} / \mathrm{ml} ; \mathrm{E}=\mathrm{PGI}_{2}$, $12.5 \mathrm{ng} / \mathrm{ml})$.

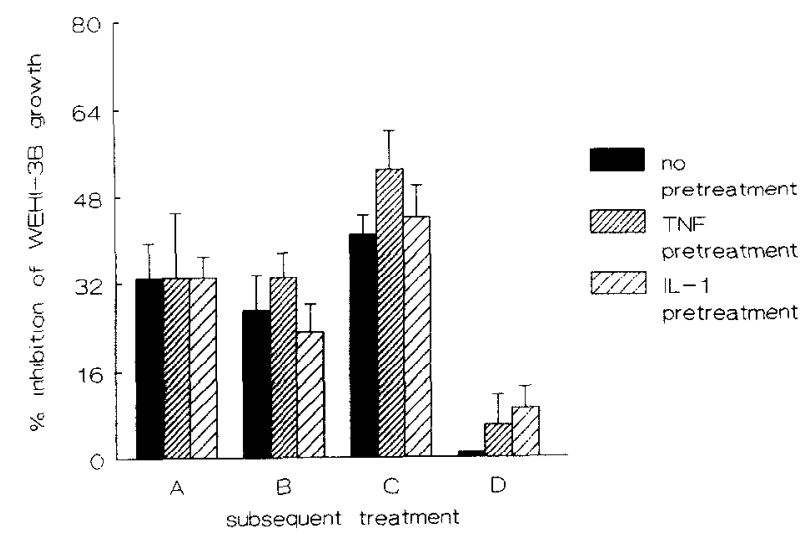

Fig. 8 Cytostatic effect on WEHI-3B cells of prior treatment with $\mathrm{IL}_{\mathrm{l} \alpha}(100 \mathrm{U} / \mathrm{ml})$ or $\mathrm{TNF} \alpha(1000 \mathrm{U} / \mathrm{ml})$ on subsequent treatment with either $\mathrm{IL}_{1 \alpha}(100 \mathrm{U} / \mathrm{ml})$ or $\mathrm{TNF} \alpha(1000 \mathrm{U} / \mathrm{ml})$ $\left(\mathrm{A}=\mathrm{TNF} \alpha ; \mathrm{B}=\mathrm{IL}_{1 \alpha} ; \mathrm{C}=\mathrm{TNF} \alpha+\mathrm{IL}_{1 \alpha} ; \mathrm{D}=\right.$ no subsequent treatment).

preciably thymidine incorporation by WEHI-3B tumor cells (Fig. 8).

All the experiments performed with IL- $1 \alpha$ were repeated with IL-1 $\beta$ with similar results (Data not shown here). 


\section{DISCUSSION}

We have reported (3), that the cytostatic effect of HrIL-1 toward WEHI-3B tumor cells was enhanced by simultaneous addition of $\mathrm{PGE}_{2}$ to tumor-cell cultures. A similar synergistic effect was now found by simultaneous addition of $\mathrm{IL}-1$ and $\mathrm{PGI}_{2}$. Another macrophage cytokine, HrTNF $\alpha$, was also synergistic with $\mathrm{PGE}_{2}$ in respect to cytostatic activity against WEHI-3B tumor cells. However, unlike IL-1, the cytostatic effect of $\mathrm{TNF} \alpha$ was not enhanced by the prostacyclin $\mathrm{PGI}_{2}$. It should be noted that $\mathrm{TNF} \alpha$ on a dose comparable basis, was less cytostatic for WEHI-3B cells than IL-1. It is also possible that the difference found now between the two cytokines in respect to their interaction with $\mathrm{PGE}_{2}$ or $\mathrm{PGI}_{2}$, could be attributed to differences in the mode of action between the two prostaglandins. Differences between $\mathrm{PGE}_{2}$ and $\mathrm{PGI}_{2}$, in their activity were described previously. Thus, while mouse resident peritoneal macrophages stimulated in vitro by LPS, produced both $\mathrm{PGE}_{2}$ and $\mathrm{PGI}_{2}$, only $\mathrm{PGE}_{2}$ had a negative regulatory effect on macrophage activation for tumor-cell killing (18). It was also reported that $\mathrm{PGE}_{2}$ was more effective than $\mathrm{PGI}_{2}$ for inhibition of granulomatous inflammation (19).

It has been reported $(2,11,20,21,22)$ that a prerequisite of antitumor activity of cytokines is their binding to cell-surface receptors. In view of this assumption, we sought to determine if pretreatment of WEHI-3B tumor cells with macrophage cytokines will render them more susceptible to subsequent exposure to prostaglandins. We found now that the synergy in cytostatic effect toward WEHI-3B cells between IL- 1 and $\mathrm{PGE}_{2}$ or $\mathrm{PGI}_{2}$ and between TNF $\alpha$ and $\mathrm{PGE}_{2}$, was also evident when WEHI-3B were first put in contact with the cytokine, washed and than cultured in presence of the prostaglandin. As in the case of simultaneous addition, pretreatment with TNF $\alpha$ did not render the WEHI-3B tumor cells more susceptible to subsequent exposure to $\mathrm{PGI}_{2}$. It has been reported (3) that WEHI-3B tumor cells, unlike other WEHI lines $(23,24)$, do not synthesize eicosanoids when stimulated with the calcium ionophore A23187. Accordingly, release of eicosanoids by WEHI-3B cells do not play a role in the enhancement of cytostatic effect of cytokines by prostaglandins.

The interrelationship between macrophage cytokines and arachidonic acid metabolites is well documented in respect to involvement of AA metabolites in induction of cytokine production $(14,16$, $25,26)$, and to modulation of cytokine activities by AA metabolites $(15,27)$. However, the mechanism of synergy between cytokines and AA products in their antitumor activity, is not yet clear. Some possibilities can be considered; a) pretreatment with either IL-1 or TNF $\alpha$ might induce increase in the total number of cell surface receptors for prostaglandins. Such a possibility was considered in respect to regulation of binding of $\mathrm{TNF} \alpha$ by treatment of cells with $\tau$-interferon $(20)$. b) pretreatment with a macrophage cytokine of WEHI-3B tumor cells might induce some damage which render the cells more susceptible to subsequent contact with prostaglandins.

It should be noted that pretreatment with either one of the cytokines did not render the WEHI-3B tumor cells more susceptible to a second exposure to cytokines. It could be that prior binding of cytokines to cell receptors prevents binding to the tumor cells of subsequently added cytokines. It has been also claimed (28) that pretreatment with IL-1 down regulates cellular response to TNF $\alpha$ by inducing decrease in the number of receptors for TNF $\alpha$.

In conclusion, our present results indicate that the interaction between macrophage cytokines and prostaglandins in enhancement of antitumor activity, might imply first binding or induction of certain modifications in the tumor cells by the macrophage cytokine resulting in increased susceptibility to subsequent exposure to prostaglandins.

\section{Acknowledgements}

The work was supported by the Dutch Cancer Foundation (Koningin Wilhelmina fund). One of us (S.B-E) is spending his sabbatical leave as Visiting Professor at the Faculty of Medicine, Erasmus University Rotterdam and as fellow of the Dutch Integral Cancer Center, Rotterdam. We are indebted to Dr. S. Gillis, IMMUNE, Seattle, U.S.A., for the generous supply of HrIL-1 and to Dr. W. Fiers, University of Ghent, Belgium, for the generous gift of $\mathrm{HrTNF} \alpha$.

\section{References}

1. Dinarello C A. Interleukin-1 Rev. Inf. Dis. 6: $51-95,1984$.

2. Aggarwal B B. Tumor necrosis factors-TNF- $\alpha$ and TNF- $\beta$ : their structure and pleiotropic biological effects, in: Drugs of the Future 12: 891-898, 1987.

3. Elliott G R, Tak C, Bonta I L. Prostaglandin $\mathrm{E}_{2}$ enhances, and leukotriene $C_{4}$ inhibits, interleukin-1 inhibition of WEHI-3B cell growth. Cancer Immunol. Immunother. 28: 74-76, 1989.

4. Espevik T, Nissen-Meyer J. A highly sensitive cell line, WEHI 164 clone 13, for measuring cytotoxic factor/tumor necrosis factor from human monocytes. J. Immunol. Meth. 95: 99-105, 1986.

5. Green P, Dobrjansky A, Chiasson M A. Murine Tumor-Necrosis-inducing factor: purification and effects on myelomonocytic leukemia cells. J. Natl. Cancer Inst. 68: 997-1003, 1982.

6. Ichinose Y, Tsao J Y, Fidler I J. Destruction of tumor cells by monokines released from activated blood monocytes; evidence for parallel and additive effects of IL-1 and TNF. Cancer Immunol Immunother. 27: 7-12, 1988.

7. Onozaki K, Matsushima K, Kleinerman E S, Saito $\mathrm{T}$, Oppenheim J J. Role of interleukin-1 in promoting human monocyte-mediated tumor cytotoxicity. J. Immunol. 135: 314-320, 1985.

8. Onozaki K, Matsushima K, Aggarwal B B, Oppenheim $\mathrm{J} \mathrm{J}$. Human interleukin-1 is a cytocidal 
factor for several tumor cell lines. J. Immunol. 135: 3962-3968, 1985

9. Sugarman B J, Aggarwal B B, Hass P E, Figari I S, Palladino M A Jr., Shepard H M.

Recombinant human tumor necrosis factor: effects on proliferation of normal and transformed cells in vitro. Science 230: 943-945, 1985.

10. Philip R, Epstein L B. Tumor necrosis factor as immunomodulator and mediator of monocyte cytotoxicity induced by itself, $\tau$-interferon and interleukin-1. Nature 323: 86-89, 1986.

11. Tsujimoto M, Yip Y K, Vilcek J. Tumor necrosis factor: specific binding and internalization in sensitive and resistant cells. Proc. Natl. Acad. Sci. 82: 7626-7630, 1985

12. Watanabe $N$, Neda $H$, Ohtusuka $Y$, Sone $H$, Yamauchi N, Maeda M, Kuriyama $H$, Niitu $Y$. Signalling pathway of tumor necrosis factor in normal and tumor cells. Cancer Immunol. Immunother. 28: 157-163, 1989.

13. Zimmerman R J. Chan A, Leadon S A. Oxidative damage in murine tumor cells treated in vitro by recombinant tumor necrosis factor. Cancer Res. 49: 1644-1648, 1989

14. Kunkel S L, Chensue S W, Phan S H. Prostaglandins as endogenous mediators of interleukin-1 production. J. Immunol. 136: 186-192, 1986.

15. Farrar W L, Humes J L. The role of arachidonic acid metabolism in the activities of Interleukin 1 and 2. J. Immunol. 135: 1153-1159, 1985.

16. Renz H, Gong J H, Schmidt A, Nain M, Gemsa D. Release of tumor necrosis factor from macrophages. Enhancement and suppression are dose-dependently regulated by prostaglandins $E_{2}$ and cyclic nucleotides. J. Immunol. 141: 2388-2393, 1988.

17. Ophir R, Ben-Efraim S, Bonta I L. Leukotriene $\mathrm{D}_{4}$ and indomethacin enhance additively the macrophage cytostatic activity towards MOPC-315 tumor cells. Int. J. Tissue Reac. IX: 189-194, 1987.

18. Taffet S M, Eurell T E, Russell S W. Regulation of macrophage-mediated tumor cell killing by prostaglandins: comparison of the effects of $\mathrm{PGE}_{2}$ and PGI. Prostaglandins 24: 763-774, 1982.
19. Parnham M J, Bonta I L, Adolfs M J P. Distinction between prostaglandin $E_{2}$ and prostacyclin as inhibitors of granulomatous inflammation. $\mathbf{J}$. Pharm. Pharmacol. 31: 565-567, 1979.

20. Aggarwal B B, Eesalu T E, Hass E P. Characterization of receptors for human tumor necrosis factor and their regulation by $\tau$-interferon. Nature 318: 665-667, 1985.

21. Hass P E, Hotchkiss A, Mohler M, Aggarwal B B. Characterization of specific high affinity receptors for human tumor necrosis factor on mouse fibroblasts. J. Biochem. 260: 12214-12218, 1985.

22. Kull F C Jr., Jacobs S, Cuatrecasas P. Cellular receptor for ${ }^{125}$ I-labelled tumor necrosis factor: specific binding, affinity labelling, and relationship to sensitivity. Proc. Natl. Acad. Sci. USA 82: $5756-5760,1985$

23. Kemoedy M S, Stobo J D, Goldyne M E. In vitro synthesis of prostaglandins and related lipids by populations of human peripheral blood mononuclear cells. Prostaglandins 20: 135-145, 1980

24. Levine L, Morgan R A, Lewis R A, Austen K F, Clark D A, Marfat A, Corey E J.

Radioimmunoassay of the leukotrienes of slow reacting substances of anaphylaxis. Proc. Natl Acad. Sci. USA 78: 7692-7696, 1981.

25. Dinarello C A. Bishai I, Rosenwasser L J, Coceani $F$. The influence of lipoxygenase inhibitors on the in vitro production of human leukocytic pyrogen and. lymphocyte activating factor (Interleukin-1). Int. J. Immunopharmac. 6: 43-50, 1984.

26. Otterness I G, Bliven M L, Eskra J D, Reinke M, Hanson D C. The pharmacologic regulation of interleukin-1 production: the role of prostaglandins. Cell Immunol. 114: 385-397, 1988.

27. Dinarello C A, Marnoy S O, Rosenwasse L J, Coceani $\mathrm{F}$. Role of arachidonate metabolism in the immunoregulatory function of human leukocytic pyrogen/lymphocyte-activating factor/interleukin-1. J. Immunol. 130: 890-895, 1983.

28. Holtmann $H$, Wallach D. Down regulation of the receptors for tumor necrosis factor by interleukin-1 and 4-phorbol-12-myristate-13-acetate. J. Immunol. 139: 1161-1167, 1987. 